\title{
For en rytmetrik ${ }^{1}$
}

\author{
Kasper Nefer Olsen
}

Poul Borum in memoriam

\section{Ouverture}

En sonet om sonetten

Fødder og q-pletter

Antik og moderne metrik

Klumpfoden (igen)

Almen indo-europæisk prosodi

Metasonettens metametrik

Pausens teori

1

Vi højtideligholder i dag 350 året for Claudio Monteverdis død, d. 29. november 1643. Hvori består Monteverdis betydning? Ja, hvis vi siger at renaissancen installerer det menneskelige subjekt* som tænkende og seende i centrum af en sækulariseret verdensorden (gennem perspektivet, solsystemets omvæltning, osv), så kan vi tilsvarende sige at det derpå følgende skridt - som karakteriserer barokken* - består i at anskue og iscenesætte dette subjekt også som følende og talende. Og netop i denne bevægelse spiller Monteverdi, inden for musikkens gebet, afgørende ind. Hvor den tidligere sakarale musik var arkitektonisk og funderet på den kirkelige - såvel teoretisk-teologiske som praktisk-liturgiske - opfattelse af sangen som ren manifestation af Helligånd, indfører Monteverdi og hans generation i den musikalske praxis et skel på den ene side mellem betydning og ord, på den anden side mellem ord og musik. På den ene side ses sproget ikke læn- 
gere blot som åndens transparente iklædning, men tværtimod som et "medium" der tilføjer betydningen endnu en dimension, nemlig den subjektive, patetiske; på den anden side høres musikken ikke længere blot som en fast arkitektonik, et formelt "stillads", hvorpå ordene så at sige "hænges op", men også tonerne forstås som et "medium" der kan modificeres af subjektet som følende og talende. På denne baggrund kan Monteverdi formulere som sit program at: l'oratione sia la padrona dell'armonia e non serva. ${ }^{2}$

Pointeringen af det subjektive moment fører i praxis til at solisten - som i den traditionelle sakrale stil blot var toneangivende for-sanger - fremhæves på bekostning af koret som trækkes tilsvarende tilbage, - for i øvrigt herefter desto lettere at kunne erstattes af en ren instrumentledsagelse. Og således fører den barokke musikopfattelse på én gang til en udvikling af sangstilen og af instrumentalmusikken. Det særligt „barokke” ved Monteverdi er imidlertid den omstændighed at han tilsyneladende helt ubesværet skifter mellem den „gamle” og den „nye” stil (prima vs seconda pratica); med fare for at vække historikerernes mishag, kunne vi således betegne Monteverdi ikke blot som en af de første moderne ${ }^{*}$, men med endnu større ret som en af de første postmoderne* komponister: en kunstner for hvem „bruddet" med den "gamle" stil ikke var ensbetydende med at give afkald på de kunstneriske indsigter der var nedfældet heri. ${ }^{3}$

\section{2}

Som dagens andet kunstneriske exempel vil jeg være så ubeskeden at fremføre et værk af mig selv, som udgangspunkt for en fortsættelse af den diskussion af metrikken som allerede længe har pågået her på Skolen. Værket er et digt, nærmere bestemt en sonet, skrevet på opfordring af en vordende digter i mit bekendtskab som udbad sig „en ordbogsdefinition af sonetten"4. Denne opgave, forekom det mig, kunne kun løses ved at skrive en sonet om sonetten (om ikke andet så fordi netop sonetten, som det vil fremgå, i sig selv er en logisk form). Mit svar lød da som følger: 
Sonetten er en slags logik for poe si, og har som sådan både form og ind hold. Man kan rime eller lade vær' (som her); det vigtige er at man tænker sig om (som altid $i$ kunsten), og vogter på at digtet færdigt kommer at bestå af fjorten vers (à el've stavelser), fordelt på to kvartetter (dem vi nu er ved at

slutte), efterfulgt af to terzetter (dem vi nu har påbegyndt), og helst således at hvor kvartetterne angi'r præmissen,

er terzetterne strofer der fuldender tanken (dog dette skal man ikke ta' så tungt: fremfor alt skal digtet jo fornøje!).

Dette er, naturligvis, en moderne - eller igen: endog postmoderne - sonet. Den betjener sig af en gammel, hæderkronet form - den såkaldte italienske sonet, som går endnu længere tilbage end til Monteverdi, nemlig til Petrarca (1304-1374) og hans sonetter til Laura; men den bruger denne klassiske form "frit", og respekterer hverken enderim (som i den traditionelle sonet, $\mathrm{fx}$ : $a b b a a b b a$ $c d c d c d$ ), eller den traditionelle faste metrik (i den klassiske sonet typisk såkaldte femfodsjamber: badám, badám, badám...). Ja, denne sonet er endda så „moderne" at den ikke tager hensyn til verselinierne, og lader både fraser og sågar enkelte ord gå på tværs heraf, - hvorved naturligvis den tætte forbindelse mellem vers og linier tenderer mod at opløses. Dog, dette er ikke usædvanligt i dag: hos Klaus Høeck finder man dem langt værre, som I sikkert ved.

Jeg skrev som sagt dette digt for at belyse sonettens væsen, i teori og praxis. Men da jeg sidenhen betragtede det nærmere, slog det mig at jeg måske uafvidende var kommet til at producere et exemplar der også kunne stimulere tanken i andre retninger, heriblandt altså ikke mindst metrikkens. Jeg kunne således ikke undgå at bemærke tydelige skift mellem 2-taktige og 
3-taktige rytmer allerede i første strofe. Det syntes indlysende at analysen, i dette tilfælde, ikke simpelthen kunne applicere den klassiske sonets faste (præ-monteverdiske) skema, for derpå at betragte de umiskendelige afvigelser herfra som - ja, netop som afvigelser. Det forekom mig indiskutabelt at denne sonet ganske enkelt ikke har en fast metrik: at den tværtimod artikulerer en fri rytme (ligesom man taler om "frie vers"). Man kan således meget vel, med dertil indrettede tegn (i det følgende bruges 1/0) markere de trykstærke over for de tryksvage stavelser; - men: kan man dermed også uden videre identificere digtets fødder, således som den klassiske metrik lister dem op? Hvorledes identificerer man overhovedet, i fraværet af et fast, på forhånd givet skema, disse metriske fødder som er rytmens egentlige enheder? At betragte denne sonets struktur som en "variant" af sonettens klassiske skema ville, forekommer det mig, være lige så rimeligt som at betragte en gaffel som en udspaltet variant af en kniv. Det er naturligvis muligt; men, som Hjelmslev ville sige: er det hensigtsmæssigt?

\section{3}

Dette spørgsmål er metodisk: det vedrører forholdet mellem metrikkens „empiri" - den i digtet givne følge af stavelser og disses indbyrdes forhold - og dens "teori": den model* for digtets rytmiske struktur som konstrueres ud fra denne empiri. Hvorledes kommer vi fra empiri til teori? Hvor begynder og hvor slutter fødderne i en "fri" række af betonede og ubetonede stavelser? Antag at jeg er givet følgende fordeling af stærk- og svagtryk:

10010110101 ;

skal jeg da skandere således:

$10|01| 01|10| 101$ ?

eller fx snarere således: 
eller hvorfor ikke således:

Hvis ikke der foreligger et historisk* overleveret metrisk skema, ${ }^{5}$ må vi, forekommer det mig, begynde helt forfra. På den ene side må vi lytte på ny, med friske øren; men på den anden side må vi også tænke os om (som der så rigtigt står i dagens text) på ny. Jeg vil begynde med det sidste, $i$ form af et postulat.

Jeg påstår at der i den poetiske rytmik findes, dagligtsprogligt udtrykt: 1'ere, 2'ere, og 3'ere - og intet derudover. Vi kan kalde disse rytmiske enheder: simpletter, dupletter og tripletter, bestående altså af henholdsvis 1, 2 og 3 stavelser (idet stavelserne er metrikkens "stof"). At der ikke findes større enheder, er indtil videre et postulat, i bedste fald en hypotese; 6 men vi kan naturligvis give den en foreløbig begrundelse ved at henvise til fx semiotikken (Peirce) eller Gestaltteorien, hvor det hævdes med stor insisteren at simple figurer ikke kan omfatte mere end 3 elementer: ved 4 eller flere ophører strukturen med at virke eller opfattes som en usammensat struktur (en 4'er opfattes fx som en $2 \times 2{ }^{\prime}$ er; en $5^{\prime}$ er som en $3+2$ 'er, osv).

Jeg noterer nu, ganske enkelt, disse grundformer ved hjælp af den musikalske rytmenotation, i praxis som ottendedele. ${ }^{7}$.

At der findes dupletter og tripletter, er jo ikke ukendt for den klassiske, græske (jeg havde nær sagt: "græssiske") metrik. Lad os med det samme notere os følgende klassiske fødder, med henblik på en nærmere betragtning ( 1 = lang stavelse; $1 / 2=$ kort stavelse):

Dupletter:

Jambe

Trokæ

Spondæ 


$\begin{array}{lll}\text { Tripletter: } & (1 / 21 / 21) & \text { Anapest } \\ & (11 / 21 / 2) & \text { Daktyl } \\ & (11 / 21) & \text { Chreticus }\end{array}$

Vi har her kun anført de vigtigste, såkaldt „ægte“ versefødder (hvortil i øvrigt spondæen ofte ikke henregnes): en fod ( $\pi \omega \varsigma$, pes) er i den klassiske metrik ikke en hvilken som helst kombination af stavelseskvantiteter, men netop kun en sådan som kan danne karakteristiske rytmiske figurer ved gentagelse eller i kombination med andre fødder.

I den „moderne klassiske“ metrik, hvor den antikke systematik søges overført på moderne sprog, er den kategori* som konstituerer rytmen ikke længere stavelsernes længde (1/1/2), men derimod tryk eller accent (1/0). Antager man imidlertid at det grundlæggende binære princip desuagtet er det samme (hvor tvivlsom denne antagelse er, skal vi strax få at se!), er det blot et spørgsmål om en anden fortolkning af den samme formalisme: man kan med andre ord fastholde det overleverede vokabular. Til benefice for sådanne genbrugere, vil vi ikke tøve med at anføre følgende enkle huskevers (en yndet sport blandt metrikere):

Ordet jambe er trokæ;

trokx er derimod en jambe.

Anapæst er anapæst;

mens daktyl er helt til hest

(for også dét er jo en jambe!).

Dog, på græsk lød ordet dáktylos,

og dette hjælper også os;

thi dáktylos er åbenlys daktyl!

\section{4}

$\mathrm{Nu}$ vil I vide at denne overførsel af den antikke notation til den moderne metrik ikke er uden visse, forholdsvis vidtrækkende teoretiske komplikationer. Nyligt har således Per Aage Brandt understreget den afgørende forskel mellem hvad han kalder la- 
tinsk og germansk metrik (LM vs GM). 8 - Vi kan indse betydningen heraf allerede ved at betragte spondæen i oversigten ovenfor. I den klassiske (latinske) metrik ville spondæen være en fod bestående af to lange stavelser, og selvom det måske er rigtigt, som purister har hævdet, at spondæen ikke er tilstrækkeligt rytmisk karakteristisk til at danne basis for et fuldgodt versemål, er der dog på den anden side intet der ligefrem forhindrer at denne kombination optræder, om så blot som en rent teoretisk mulighed. I det germanske system, derimod, er det en anden sag: tryk eller accent er en rent kategoriel ${ }^{*}$ størrelse som kun kan realiseres gennem en realiseret forskel, og dette indebærer, i sin konsekvens, at der ikke kan findes en spondx $i$ germansk metrik. En fod, i det germanskesystem, må nødvendigvis i sig artikulere en accentforskel: den kan ikke, for nu at pointere pointen, nøjes med at artikulere en accentlighed! Spondæen kan optræde, i det mindste forbigående, i klassisk græsk metrik, fordi det her giver mening at sige at 2 korte stavelser ækvivalerer 1 lang (således at spondæen $\mathrm{fx}$ kan vikariere for en daktyl); men at hævde, i en germansk metrik, at 2 svage tryk under omstændigheder skulle kunne ækvivalere 1 stærkt, ville unægtelig være rendyrket nonsens!

I hvert fald vil jeg ikke acceptere spondæen i min version af en moderne metrik, - i hvad jeg vil kalde min rytmetrik. Jeg vil derimod fastholde det kategorielle princip, og hævde at der i hver rytmisk enhed findes ét og kun et tryk, placeret på én og kun en af stavelserne (1, 2, eller 3). Dette giver mig, som man vil indse, følgende 6 brikker at rykke med:

Simplet:

Dupletter: $\quad$ (01) Jambe $\quad$ (10) Trokæ

Tripletter. (001) Anapæest (010)? (100) Daktyl

Vi bemærker strax at der mangler en klassisk term for en af tripletterne. Slår man efter i den klassiske metrik, vil man ganske vist uden større besvær kunne finde en tredie „ægte" versefod 
med tre stavelser, nemlig den såkaldte chreticus. Denne fod har imidlertid, som allerede anført, formen (1'1/2 1), hvilket givetvis er fuldt ud acceptabelt i den græske prosodi, men ikke desto mindre ligeså fuldt ud uantageligt i den germanske, og det af samme grund som anfægtede spondæen: chreticus'en måtte her fortolkes som en fod med to stærktryk - hvilket, hævder jeg, er umuligt.

Den kombination, jeg savner, er en anden, nemlig formen: $(1 / 211 / 2)$, dvs i den germanske metrik: (0 10$)$. At en sådan form almindeligvis ikke gælder for en ægte versefod i den klassiske metrik, skyldes atter de samme forhold som tendentielt deklasserede spondæen: kombinationen (1/2 11/2) ækvivalerer 2 lange stavelser, dvs denne fod opfattes som forbigående "erstatning" for anapæst eller daktyl. I det germanske system bliver til gengæld denne figur, fortolket som accentrytme, ikke blot mulig, men formentlig uundværlig; jeg foreslå at benævne den: antichreticus. 9

\section{5}

Min afvisning af den klassiske chreticus får imidlertid også en anden konsekvens. I det tilfælde hvor jeg virkelig møder en sluttet accentfølge af formen ( $\left.\begin{array}{lll}0 & 0 & 1\end{array}\right)$ - hvilket jeg jo på ingen måde $a$ priori* $^{*}$ kan udelukke - tvinges jeg til at gøre hvad der var aldeles forbudt i den klassiske metrik: jeg tvinges til at analysere figuren som en følge af en fod på to stavelser og en fod - på bare én enkelt stavelse (hvad jeg her kalder en "simplet").
Altså ikke:
(1 $\left.\begin{array}{lll}1 & 0 & 1\end{array}\right)$ men derimod:
(10) (1) .

I den klasiske metrik opereres, som sagt, ikke med en sådan "fod" bestående af én enkelt stavelse - og det rimeligvis ud fra den ikke urigtige betragtning at rytmen også dér forudsætter et samspil mellem forskelle (de metriske figurer må omfatte mere end én stavelse). Imidlertid viser allerede ovenstående exempel at vi - såfremt den her foreslåede rytmetrik skal være konsistent - i den germanske metrik ikke kommer uden om at operere med en enkeltfod. ${ }^{10}$ Just elegant er den jo ikke: i daglig tale kunne man 
føle sig fristet til at referere til fænomenet med betegnelsen klumpfod - Oidipos, som det ville hedde på græsk. Der er tale om en figur som midlertidigt bringer selve rytmen til standsning; men at afvise et sådant fænomen ud fra en formodet normativ forestilling om at rytmen ikke "må standses, ville på den anden side være helt malplaceret: vi kender lignende fænomener fra musikken ( $f x$ den såkaldte fermat: en dvælen på en given nodeværdi, ud over dennes nominelle længde), og fra poesien selv kender vi klump-foden fra så klassiske former som:

$O !, \ldots$

Rent teoretisk er klumpfoden formentlig en art fortætning eller kontraktion af flere tryk (eller måske af stærktryk og pause) til en art "dobbelttryk" (ligesom man i musikken kender til "dobbeltslag"): enhver simplet er betonet, og allerede heraf følger at betoningen her har en "tungere" karakter end de mere "mobile" tryk i de sammensatte fødder.

Lad mig i øvrigt tilføje at spørgsmålet om simpletten er et af de punkter hvor den klassiske metrik forekommer mig særligt uklar og inkonsistent. I forbindelse med sonetten - hvor vers à 11 stavelser, såkaldte hendekasyllabler, som nævnt er normen - tales således gladeligt om "femfodsjamber", uagtet 5 jamber ikke giver mere end 10 stavelser, og metrum'et derfor i det mindste burde kaldes 51/2-fodsjambisk. Hvad bliver der af denne halve fod? I dette tilfælde synes den at forblive svævende over jorden...11

\section{6}

Det skal nævnes her at den modstilling mellem "latinsk" og "germansk" metrik, som senest Per Aage Brandt har hævdet, formentlig kun besidder ideal* gyldighed. I virkeligheden findes der "germanske" tryk (accenter) selv på oldgræsk, såvel som der findes korte og lange stavelser på nudansk; det forholder sig blot 
således at trykket på oldgræsk i poesien aldeles underordnes stavelseslængderne, mens det på nudansk er omvendt. Allerede i den latinske poesi bryder det - allerede dengang "klassiske“ græske, rent kvantitetstællende system imidlertid sammen, under ",trykket" fra en mere dominerende accent-baseret diktion. Et sprog som moderne fransk er en mellemform: de fleste grammatikker vil indskærpe at der i moderne fransk ikke findes germanske stærktryk; og dog lader den poetiske rytme sig også her (eftersom der trods alt ikke er tale om en rent kvantificerende metrik) artikulere som musikalske accenter, i rytmetrikkens forstand (notationen af cæsuren vender vi tilbage til):
$\left(\begin{array}{lll}0 & 0 & 1\end{array}\right)$
$\left(\begin{array}{llll}0 & 0 & 1\end{array}\right)$
$(\varnothing 00)(10)$

Il y $a$ une horloge / qui ne sonne pas

(Rimbaud).

Den klassiske metrik bliver således mere og mere "ugyldig" op igennem den indo-europæiske sprogudvikling, ligesom den moderne metrik ville blive mere og mere "ugyldig" hvis man spolede tiden tilbage; men ingen af systemerne kan givetvis fuldstændigt underlægge sig det andet.

På den ene side er det altså rigtigt, teoretisk set, at operere med en skelnen mellem „latinsk" og "germansk"; på den anden side vil formentlig ethvert virkeligt sprog være en mellemform, et eller andet sted $\mathrm{i}$ et kontinuum* mellem de to extremer (det kunne være interessant at undersøge trykforholdene på fx moderne finsk eller litauisk, ud fra denne synsvinkel). Den generelle tendens i indo-europæisk synes dog at være bevægelsen bort fra den altovervejende kvantitative, kort/lang-metrik - som i oldgræsk og sanskrit - og henimod en mere eller mindre markeret (marcato, siger musikerne) form for accent-baseret metrik, - således i det højt avancerede idiom nutidsdansk, som vi jo naturligvis, som gode grundtvigianere, må betragte som sproghistoriens ypperste blomst! 
7

Jeg foreslår nu, ud fra disse teoretiske betragtninger, følgende formale analyse af min egen, ovenfor citerede "metasonet" (for notationen, cf note 7):

$(010)(10)(1)(010)(10)$

(1) $(\varnothing 01)(010)(10)(1)(01$

0) $(\varnothing 10)(101 / 20)(10)(1)(0$

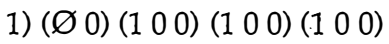

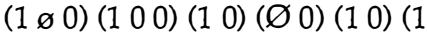

0) $(10)(10)(101 / 20)(1)(0$

$10)(1 ø 0)(10)\left(\begin{array}{lll}1 & 0 & 0\end{array}\right)(\varnothing 01)$

$\left(\begin{array}{lll}0 & 1 & 0)\end{array}\right)\left(\begin{array}{l}1 \\ 1\end{array}\right)(ø 10)(10)(10)$

(1 0) $(\varnothing 10)(10)(1 / 2010)(\varnothing 1$

0) (1 0) (1 000$)(\varnothing 0)(1)\left(\begin{array}{lll}0 & 1 & 0\end{array}\right)(\varnothing$

0) (1) $\left(0 \begin{array}{lll}1 & 0\end{array}\right)(010)(010)(\varnothing$

0) $\left(\begin{array}{lll}0 & 1 & 0\end{array}\right)\left(\begin{array}{lll}0 & 1 & 0\end{array}\right)(1)\left(\begin{array}{lll}1 & 0 & 0\end{array}\right)$

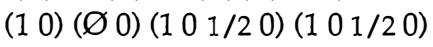

(1) $\left(\varnothing \begin{array}{lll}1 & 0\end{array}\right)\left(\begin{array}{lll}1 & 0\end{array}\right)\left(\begin{array}{lll}1 & 0 & 0\end{array}\right)\left(\begin{array}{lll}0 & 1 & 0\end{array}\right)$

- Det vil sige at du betragter fx ordet sonetten, $i$ første vers, som en enhed, $i$ stedet for, som $i$ den traditionelle analyse, at splitte det op...

Netop. Jeg påstår at sonetten virkelig er - metrisk set - en enhed, og at det metrisk høres som en enhed, som en triplet. Men det kommer selvfølgelig an på, hvilken type oplæser mit digt falder i hænderne på: man kunne jo tænke sig en neo-klassicist som helt enkelt ikke vil anerkende moderne, fri metrik, og som derfor vil insistere og skandaløst skandere:

Sonét I ten ér | en slágs | logîk | for pó I e ... osv,

med de - i uegentlig forstand - „barokke” følger dette ville have. - I min moderne teori går derimod hvad jeg vil kalde den rytmiske oplevelsesenhed på afgørende vis forud for inddelingen i fødder, og 
jeg påstår - men her er vi naturligvis ude på fænomenologiens* gyngende grund - at dette faktisk er mere adækvat for det digt der foreligger på papiret.

- Men lidt senere gør du jo så selv noget andet; fx i niende vers hvor du gør to terzetter til én blok, selvom det jo er to distinkte ord...

Der er nok her tale om to forskellige spørgsmål. Jeg hævder den rytmiske enheds enhed; men jeg hævder ikke ordets enhed, i denne forbindelse...

- Nej, for $i$ tiende vers tager du jo den sidste stavelse fra terzetterne og henregner den til den efterfølgende fod. Det forekommer mig, faktisk, meget urigtigt. Hvorfor ikke lade den være en 4'er, så de hænger sammen?

Det skyldes jo nok at jeg nødigt ser en 4'er med kun ét tryk. Når jeg har ladet visse dupletter forbinde sig til kvadrupletter i denne analyse, er det hver gang under forudsætning af at de to dupletter har hvert sit stærktryk; pointen ved at forbinde dem, er udelukkende at vi da kan antage det ene af disse som relativt underordnet det andet (såkaldt "bitryk"), således som i kómmer àt be(stå) hvor at får et relativt svagere tryk. Men i terzetterne kan jeg ikke finde noget sted at placere et sådant bitryk (at placere et tryk på -ne er naturligvis udelukket!). Til gengæld opnår jeg nu at vi i vers 12 endnu engang får to ens fødder (anti-chreticus'er) efter hinanden, hvilket jo er ganske tilfredsstillende...

$-N a ̊, j a \ldots$

Og disse to tripletter kan så måske - det vil jeg ikke afvise - forbindes til én "6-plet" med to ulige tryk, måske med bitryk på stròfer. Hvorved også din æstetiske fordring ville kunne tilfredsstilles.

Serier af ens fødder - som i højere grad var normen i klassikken $^{12}$ - er jo heller ikke i moderne metrik at foragte. Det var således også en stor tilfredsstillelse for mig at de to første vers i me- 
tasonetten viste sig at kunne opfattes som temmelig regelmæssige, nemlig som følger:

anti-chr tr simpl anti-chr tr simpl anap anti-chr tr simpl antichr...

(hvor den indskudte anapæst i øvrigt ikke tilfældigt, tror jeg, står i forbindelse med en pause; herom senere).

- Jeg forstår nu ikke hvorfor poesi skal opfattes som trokæ + simplet; det kunne lige så godt være en anapæst, for mig at se...

Det har du måske ret i... Det ville ikke være uforeneligt med teorien, i hvert fald, - selvom det altså ville gå lidt ud over den overordnede rytme. Jeg har nok tænkt at dette lidt respektløse afbræk i ordet poesi også måtte markeres i rytmen; men jeg indrømmer at det er lidt uklart...

Hvorom alting er, vil det hverken være nødvendigt eller blot muligt for metrikken at operere med et "hvert ord sin fod"-princip. Jeg vil gøre opmærksom på at der jo findes énstavelsesord, og at disse må kunne forbinde sig med andre énstavelsesord og danne fødder (som i: dem vi nu er ved at...). Og samtidig findes der ord med et ganske stort antal stavelser (såsom: desoxyribonukleinsyrer) som det ville være urimeligt at kræve særlige fx 10-pletter for at formalisere. Jeg finder det derfor ganske naturligt at artikulationen af de metriske fødder ikke nødvendigvis falder sammen med artikulationen af ordene - selvom du givetvis har ret $i$ at det er et af de steder hvor en alt for absurd skandering ville afsløre sig.

Et ord som femstavelsesord (et af de sjældne ord der betegner sig selv: et homonym, ifølge Per Aage Brandt) vil, for mig at se, måtte analyseres som en følge af flere fødder. Ud fra en slags kommutationsprøve (hvor jeg fx sammenholder med ord som syttenstavelsesord og femstavelsesadverbium) mener jeg således at kunne lokalisere hele 3 tryk, således: 
(1) $\quad\left(\begin{array}{lll}1 & 0 & 0\end{array}\right)$

fem stavelses ord

- Den er nu også lidt kompliceret, din teori...

Selvfølgelig er den kompliceret!

8

Imidlertid er dette kun begyndelsen. Som det fremgår af ovenstående analyse, må metrikken også tage højde for pauserne i den rytmiske skandering af digtet. Af pauser findes der to slags: vi kan kalde dem implicitte og explicitte. - Når vi overhovedet hævder at det er muligt at afgrænse fødder som rytmiske oplevelsesenheder, må vi dermed også hævde at der findes noget „imellem" disse enheder. Dette "imellem" kan (og skal) imidlertid ikke nødvendigvis høres som sådan: det kan derfor siges at bestå af implicitte pauser. - Men derudover findes der åbenbart også pauser som ikke blot kan, men skal høres: dette er da de explicitte pauser, som fx efter $\mathrm{O} v e !$...

De explicitte pauser, vil jeg mene, indgår i artikulationen af rytme og metrum på lige fod, så at sige, med de betonede og ubetonede stavelser (i moderne metrik); men det er klart at det metodisk åbner nye vanskeligheder at skulle inddrage også pauserne i rytmetrikken. Hvornår foreligger der en explicit pause, og ikke blot en implicit som skal „over-høres"? Man kan være så heldig at digteren har benyttet sig af forskellige former for punktuation m.m. som ofte vil indicere explicitte pauser; men selv hvor det er tilfældet, kan det næppe betragtes som et tilstrækkelig sikkert kriterium. Vi udleveres altså endnu engang til øret, på ny.

Betragter I nu atter min egen analyse af metasonetten, vil I bemærke at jeg har noteret ikke mindre end 12 explicitte pauser (angivet ved $\varnothing$ eller $\varnothing$ ). I almindelighed vil vi - af indlysende grunde - kunne forvente at antallet af pauser ikke er uden forbindelse med antallet af vers (eftersom vers „oprindeligt" er ånde- 
drætsbetingede enheder); i dette tilfælde bemærker vi at at en pause ofte lægges efter første stavelse i versets skriftbillede: dette hænger naturligvis sammen med hvad jeg tidligere bemærkede, nemlig at vers og "linieføring"i denne moderne form ikke følges ad (mere præcist: at der i rytmen vakles mellem det "skæve" 11metrum og det mere taktfaste 12-metrum). ${ }^{13}$

I hvert enkelt tilfælde har jeg indskrevet pausen i en fod (som konvention har jeg, indtil videre, fastsat at pausen regnes til den efterfølgende fod). Indføringen af pauser, bemærker vi videre, anfægter ikke det grundlæggende princip i rytmetrikken at der ikke findes fødder med mere end ét tryk for hver 3 stavelser. For så vidt fødderne ikke nødvendigvis følger linierne, dvs at en fod kan begynde i den ene linie og først afsluttes i den følgende, kan vi af og til komme ud for det ejendommelige at en pause afslutter en linie (således linierne 10 og 11); det kan se underligt ud, men er i virkeligheden ganske naturligt, og kan sammenlignes med et typografisk fænomen som indrykning ved nyt afsnit (bemærk at pausen modsvarer "synligt" komma i linie 10, „usynligt" komma i linie 11).

Ikke desto mindre fører dette til det ikke helt trivielle spørgsmål: kan virkelig ikke blot verset, men også hele digtet indledes med en pause? Det ser jeg faktisk intet til hinder for. Fra musikken kender man notationer som følgende (Beethoven, 5. Symfoni, 1. takt):14

(2/4) \# da da da I da-aa-aa-aa .

At anføre en sådan pause, kan synes ejendommeligt - for så vidt den jo blot slutter sig til en i princippet uendelig forudgående pause. Det har imidlertid i musikken sin grund ikke blot i dirigentens praxis (som, i ovenstående tilfælde, faktisk vil artikulere en indledende pause!), men fremfor alt i værkets rytmiske strukturer. I rytmetrikkens tilfælde kan vi tænke os fænomenet begrundet i princippet om højst 3 stavelser pr fod, således i følgende Bibel-"vers": 
$(\varnothing 00)\left(\begin{array}{lllll}1 & 0 & 0\end{array}\right)(100) \quad(1) \quad(1000) \quad(100 \mid 0)$

I begyndelsen skabte Gud himlen og jorden. (Og...)

Her udgør de to første stavelser en „optakt" som vi imidlertid må notere som en selvstændig fod, da vi ikke i rytmetrikken vil tillade et enkelt stærktryk at organisere hele 4 omkringliggende svagtryk. (En passant bemærket viser dette exempel hvorledes kombinationen duplet + simplet kan fremstå ved transformation af en triplet, jvfr den tidligere indførelse af „klumpfoden“: verset ville være langt mere regelmæssigt hvis også skabte Gud opfattedes som daktyl; men semantikken påbyder - rimeligvis - en særlig betoning og udhævelse af netop stavelsen $\mathrm{Gud}$ ).

Imidlertid lader det sig ikke nægte at alle disse i og for sig om ikke trivielle, så dog harmløse betragtninger fører én ting med sig, som visse vil kunne forventes at finde urimelig, ja monstrøs: i exemplet ovenfor optræder ikke blot en pause som den første "stavelse"; den tilskrives endog stærktrykket i den indledende fod! Kan dette virkelig tænkes? Er det virkelig hensigtsmæssigt? Eller ser vi ikke her snarere - som så ofte før - formaliseringens omslag i teoretisk rablen? Jeg vil naturligvis mene at denne notation er ikke blot forsvarlig, men også hensigtsmæssig og sågar smuk (selvom jeg indrømmer at det i metasonettens linier 10 og 11 ser lidt ejendommeligt ud!). Lad mig til støtte herfor henvise til den klassiske metriks begreb om cæsuren, det obligate „brud“ midtvejs i verset, $\mathrm{f} x \mathrm{i}$ hexameteret. Et sådant brud er, i min teori, en explicit pause. Hvis nu metrum'et er således at cæsuren efterfølges af en eller flere tryksvage stavelser, bliver det en naturlig betragtning at høre disse som "udklingen" af en metrisk begivenhed* som ikke selv faldt sammen med en stavelse, men som alligevel i højeste grad trængte sig på og måtte markeres i skanderingen, nemlig i form af cæsurens "ophold" (således i Rimbaud-exemplet ovenfor). Og herfra er der kun ganske kort til at betragte cæsuren som en betonet pause. (Hvorvidt denne betragtning kan finde mere systematisk anvendelse også i klassisk metrik, har jeg endnu ingen bestemt mening om). 
Cæsuren kunne således være endnu et exempel på et rytmisk element som lå fast $\mathrm{i}$ klassikken, men som i moderne poesi er „,frisat" og kan antræffes hvor som helst, i form af betonede pauser. Der gælder dog tilsyneladende stadig visse regler som vi kan håbe at kunne ophøje til objektive kriterier, forpligtende for den rytmetriske analyse. Jeg mener således at kunne hævde følgende sætninger:

\section{Sætning 1:}

En pause kan kun være betonet hvis den efterfølges af mindst én (højst to) ubetonede stavelser.

(Dette følger, i forening med konventionen om at en pause henregnes til efterfølgende fod, af at ingen fod må have mere end ét stærktryk).

Sætning 2:

En pause kan ikke være betonet, hvis den efterfølger en (nødvendigvis betonet) simplet. Efterfølges pausen af højst én ubetonet stavelse, underordnes begge simplettens stærktryk (der fremstår således en form for "sprængt daktyl “); i modsat fald indgår pausen $i$ en efterfølgende anapæst.

Exempler på sidste sætning (som ligeledes følger af allerede anførte postulater og konventioner, herunder især antagelsen af et "dobbelttryk" i simpletten) finder vi i metasonettens linier 5 og 7 (,sprængt daktyl“), samt linie 2 (simplet + anapæst). Forskellige andre bemærkelsesværdige muligheder finder vi i linierne 3 (ubetonet pause i anti-chreticus), 4 (betonet pause efter jambe), og 5 (betonet pause efter trokæ).

Hvorvidt denne aritmetik for pausernes tryk kan stå for en nærmere prøvelse - må være op til en nærmere prøvelse. 


\section{Noter}

1. Nærværende text reproducerer en forelæsning holdt på Forfatterskolen, Charlottenborg, København, d. 29. november 1993. Som sådan er den et uddrag af et endnu upubliceret manuskript indeholdende hele dette efterårs forelæsninger. Indskud i kursiv er indlæg fra Forfatterskolens elever, som hermed endnu engang takkes for deres indsats. Tilegnelsen gælder, naturligvis, mindet om Forfatterskolens utrættelige initiator, poesiens inkarnation i sin epoke, digteren, humoristen og ironikeren, tørvetrillernes skræk, den altfavnende og selvudslettende...

Asterisker (*) henviser til opslagsord i min Labyrint - für freie Geister, Det Kgl. danske Kunstakademi, 1993, der tjente som grundbog for Forfatterskolens filosofikursus. (Note tilføjet 1996)

2. „Vokalfremførelsen skal være harmoniens herskerinde, ikke dens tjenerinde".

3. Til illuminering af disse betragtninger afspilledes her to satser - i hver sin stil - af Claudio Monterverdis Messa a quattro Voci da Capella (op posth, 1650).

4. Den vordende digter var maleren Marianne Grønnow, som også varetager billedsiden i nærværende nummer af PASSAGE. Sonetten om sonetten blev trykt første gang i PASSAGE 16/94. (1996)

5. Og selv på en sådan historisk basis kan det alligevel let gå galt. For vel kan jeg altid finde en hoben exempler på at en given periode følger denne eller hin konvention; men hvad stiller jeg op med undtagelserne, dvs de egentlige litterære begivenheder? Hvornår er der tale om et brud på eller en afvigelse fra normen, og hvornår er der tale om en ny norm? Det kan der naturligvis ikke gives noget immanent* historisk kriterium for, og således er den historiske tilgang ikke et hår mere velfunderet end en hvilken som helst anden udøvelse af den subjektive smagskompetens. Den følgende note anfører et exempel på hvorledes selv den mest solide historiske fundering ikke kan forhindre meningsløse cirkelslutninger, udsprunget af dette metodiske paradox. (1996)

6. I Jørgen Fafners imponerende totalhistorie for dansk metrik, finder vi (Digt og form, 1989, p 49f) følgende exempel på en "tetrasyllabisk" versefod, angiveligt „i sin rene forekomst sjælden":

Jeg har elsket dig, så længe jeg kan mindẹs

(Mogens Dam)

$0010|0010| 0010$

med den klassicistisk forsigtige bemærkning at „med Kai Normann Andersens kønne melodi er der nu alligevel kommet god pop-kunst ud af det". Ifølge Fafner findes der således fødder som organiserer mere end tre stavelser, omend altså kun „lige på kanten” af det normativt antage- 
lige: der krævedes en ferm komponist for at „redde“ det i og for sig frivole tetrasyllabiske versemål. Netop denne betragtning præsupponerer imidlertid at "tetrasyllablen" faktisk forefandtes i texten "før" den blev tonesat. I virkeligheden er det naturligvis (som Fafner i øvrigt selv bemærker hvad angår det efterfølgende exempel "Snapsevisen“) omvendt: det er Normann Andersens melodi der får Fafner til at høre verset som "tetrasyllabisk"; uden den ville han som enhver anden have skanderet simpelt trokæisk:

\section{$10|10| 10|10| 10 \mid 10$.}

Det afgørende er her ikke så meget spørgsmålet hvorvidt der alligevel "findes" tetrasyllabiske vers eller ej, men erkendelsen af at en metrisk empirisme, dvs en analyse som ikke forpligter sig på et apriorisk sæt af kategorier, altid vil ende op med sådanne "indecidable" marginaltilfælde - af den simple grund at kunsten aldrig kun er regelbundet. Netop fordi kunsten ikke er det, må teorien imidlertid påtage sig reglens strenghed. (1996)

7. Denne suggestive, men typografisk besværlige notationsform er her erstattet af en enklere, som samler elementerne i parenteser. Elementerne i rytmetrikken (som forklaret i det følgende) er: 1 = stærktryk; $0=$ svagtryk; $1 / 2=$ bitryk; $\varnothing=$ pause; $\varnothing=$ betonet pause. Derimod noteres den antikke metriks kvantiteter: $1=$ lang; $1 / 2=$ kort, hvilket - som en ikke ligegyldig sidegevinst - gør det muligt for læseren i ét blik at konstatere, om vi befinder os i en accenttællende eller en kvantitetstællende metrik (hvis tegnet 0 forekommer, er det første tilfældet; hvis der kun forekommer 1 og 1/2, det sidste, - idet naturligvis ingen accentmetrik er mulig helt uden svagtryk). Hvad der har fået hidtidig metrisk teori og analyse til stædigt at fastholde den samme notation for to væsentligt forskellige fænomener, med hele den usigelige forvirring dette har medført, er en af moderne litteraturteoris mange gåder. (1996)

8. Cf Per Aage Brandt: „Metriske meditationer", in: PASSAGE 1112/92, pp 183-192.

9. I Madvigs berømte Latinsk Sproglære til Skolebrug (1844), anføres benævnelsen amphibrachys for den dertil svarende - men altså udtrykkeligt uægte - figur i klassisk metrik. (Madvigs lærebog er delvis genoptrykt i nyere tid, men - NB! - uden afsnittet om metrikken! (1996)).

10. Edgar Allan Poe, som ellers i sin Rationale of Verse forfægter en kontinuitet snarere end et brud mellem klassisk og moderne metrik, markerer sig som en overraskende varm fortaler for en sådan enkeltfod: „It is a perfect foot - the most important in all verse - and consists of a single long syllable; but the length of this syllable varies" (Complete Tales and Poems, New York 1975, p 912). 
11. Dette problem hænger sammen med det klassiske spørgsmål om katalexen: hvorledes man skal forholde sig til det som enhver kan høre foregå „mellem linierne”, men som er "usynligt” i skriftbilledet (cf Fafner, op cit, p 65ff). Hvis man, i en germansk metrik, opfatter et 11-stavelsesvers som bestemt ved 5 dupletter, må man stiltiende forudsætte at den tiloversblevne stavelse finder sit komplement i et "usynligt", betonet element mellem de skrevne vers (en ubetonet stavelse kan ikke danne fod alene!). Dette medfører imidlertid, for det første, at en strofe af $n$ "femfodsjamber" meget vel kan få flere end $5 n$ stærktryk, hvad der ikke synes at være noget argument for terminologien. For det andet, endvidere, at en sådan strofes "jambiske" karakter undermineres af disse "vagante" stærktryk. Det synes at være tilfældet $\mathrm{fx}$ i den strofe af Jens Baggesen, som vi finder i Fafners afsnit om "Femfodsjambiske strofer" (op cit, p 156); den jambiskerytme tipper her umiskendeligt over i en trokæisk, med noget der næsten ligner en forstoppelse af stærktryk midtvejs i strofen:

Der var en Tid, da jeg var meget lille, Min hele Krop var kun en Alen lang; Sødt, naar jeg denne tænker, Taarer trille, Og derfor tænker jeg den mangen Gang

som jeg læser:

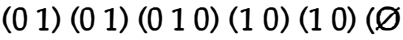

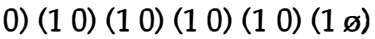

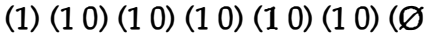

0) $(10)(10)(10)(10)(1 ø)$.

Bemærk at den sidste fod stadig holdes svævende! (1996)

12. Forelæsningen antyder her kun lige det perspektiv at den moderne, "frie" versedannelse - idet den opgiver de på forhånd givne versemål, der måske i virkeligheden ikke så meget er ,"klassiske" som snarere klassicistiske - på ny bliver opmærksom på hvad der var den antikke poesis oprindelige drivkraft, nemlig gentagelsen af den enkelte (an und für sich prægnante) fod. (1996)

13. Cf den tilsvarende „taktløse” brug af rim i „metasonetten”. (1996) 14. Cf evt min analyse af dette musikalske fænomen $i$ "Quelques notes sur le métalangage et le jeu", in: Travaux du Cercle Linguistique de Copenhague, 1993, 24, pp 78-88. 